\title{
Optimization of Conditions for the Maximum Bacteriocin Production of Enterococcus faecium DB1 Using Response Surface Methodology
}

\author{
Hye Young Choi, Joon Soo Kim, and Wang June Kim* \\ Department of Food Science and Technology, Dongguk University, Seoul 100-715, Korea
}

\begin{abstract}
The bacteriocin-producing lactic acid bacteria Enterococcus faecium DB1 was isolated from Korean traditional gajami sikhae. Culture conditions were optimized by response surface methodology (RSM) to maximize bacteriocin DB1 production. E. faecium DB1 displayed the highest bacteriocin activity when grown in modified MRS medium containing sucrose, rather than glucose, as a carbon source. The effects of temperature, initial $\mathrm{pH}$, and sucrose concentration were tested to determine the optimum conditions for maximum bacteriocin production by E. faecium DB1. A central composite design was used to control the three variables in the experiment. RSM revealed that the optimum values for bacteriocin production were $27.66 \mathrm{~g} / \mathrm{L}$ sucrose, temperature of $34.37^{\circ} \mathrm{C}$, and an initial $\mathrm{pH}$ of 6.54 . A 2.08-fold increase in bacteriocin production was obtained with sucrose-containing MRS medium compared to production in standard MRS medium.
\end{abstract}

Key words: bacteriocin, Enterococcus faecium, gajami sikhae, optimization, response surface methodology

\section{Introduction}

In recent years, bacteriocins are potentially useful as natural replacements for synthetic food preservatives against antibiotic resistant pathogens and spoilage bacteria. Bacteriocins are ribosomally synthesized, hydrophobic or amphiphilic peptides of bacterial origin. Although bacteriocins may be produced by Gram-positive and Gram-negative bacteria, those from lactic acid bacteria (LAB) are of particular interest due to their potential use in the food industry as natural safe food preservatives (Cleveland et al., 2001; Kim, 1993; O'Sullivan et al., 2002). They have relatively narrow antimicrobial spectra as they are only lethal to bacteria closely related to the producer strain, are digested by protease (Ross et al., 1999; Senesi et al., 2001).

Bacteriocins act on target cell membranes resulting pore formation, leads to a rapid efflux of small cytoplasmic molecules, ions from the target cells and the collapse of the proton motive force (PMF), leading to the cell death (Jack et al., 1995). Due to the different modes of antibacterial action, these antibacterial peptides (ABP) circumvent the problems related to the development of antibiotic resistance.

\footnotetext{
*Corresponding author: Wang June Kim, Department of Food Science and Technology, Dongguk University, Seoul 100-715, Korea. Tel: 82-2-2260-3373, Fax: 82-2-2260-3373, E-mail: wjkim@dongguk.edu
}

As reported by Cotter et al. (2005), "bacteriocins can be used to confer a rudimentary form of innate immunity to foodstuffs", for this reason, production of bacteriocins by $\mathrm{LAB}$ and non-LAB strains, as well as their application to the biopreservation of fermented and non-fermented foods have been investigated extensively (Settanni and Corsetti, 2008).

Bacteria of the genus Enterococcus are widespread in various traditional food systems, especially those from animal origin, such as dairy products (Foulquie' Moreno et al., 2006). This genus can become an important part of the fermented dairy microflora and its source seems to be not necessary related with faecal contamination (Giraffa, 2003). Bacteriocins produced by enterococci have gained interest because many species of enterococci are capable of producing a variety of enterocins with activity against Listeria monocytogenes, Staphylococcus aureus and Clostridium spp. (Floriano et al., 1998; Franz et al., 1999; Gelsomino et al., 2001). Therefore, the use of enterocins or the enterocinproducing starter culture or co-culture, during food fermentation has received special attention as an excellent preservation method to control emergent pathogenic bacteria (Giraffa et al., 1995; Sabia et al., 2002).

Bacteriocin production can be influenced by culture conditions, among them are medium composition, incubation atmosphere, $\mathrm{pH}$, temperature, and microorganism growth phase (Gänzle et al., 1999). Therefore, the optimization of environmental conditions is very important for the enhance- 
ment of bacteriocin production. The effects of $\mathrm{pH}$ and temperature are very important for bacteriocin production and have been studied by several LAB such as Lactococcus lactis (De Vuyst and Vandamme, 1995), Lactobacillus casei (Vignolo et al., 1995) and Leuconostoc mensenteroides (Krier et al., 1998). Optimization of medium by the classic method involves changing one independent variable while fixing all others at a fixed level. This is extremely timeconsuming and expensive for a large number of variables (Adimarayana et al., 2003) and also may result in wrong conclusions (Oh et al., 1995). Response surface methodology (RSM) is a collection of statistical techniques for designing experiments, building models, evaluating the effects of factors, and searching optimum condition of factors for desirable responses (Li et al., 2001). This method was successfully applied in many areas of biotechnology, including some recent studies on bacteriocin production (Leal-Sánchez et al., 2002; Li et al., 2001).

In our previous paper, we have reported that Enterococcus faecium DB1, isolated from Korean traditional gajami shikae, produced a narrow spectrum bacteriocin DB1 that inhibits the growth of Listeria monocytogenes, Lactobacillus curvatus and Pediococcus acidilactici. Inactivation of antimicrobial activity was observed after treatment with proteolytic enzymes and $\alpha$-amylase, and it was heat stabile, $16.5 \mathrm{kDa}$ in size. Maximum activity $(1,280 \mathrm{AU} / \mathrm{mL})$ against L. monocytogenes was observed in MRS broth (Lee and Kim, 2010).

The purpose of this study was to evaluate the effect of three variables including temperature, initial $\mathrm{pH}$, and sucrose concentration in bacteriocin production and to optimize culture condition for production of bacteriocin by Enterococcus faecium DB1 through response surface methodology (RSM).

\section{Materials and Methods}

\section{Bacterial strains and media}

The bacteriocin DB1-producing strain used in this study was Enterococcus feacium DB1, previously isolated from gajami sikhae. L. monocytogenes ATCC 19111 was used as the indicator strain for the bacteriocin activity assay. All tested microorganisms were maintained in glycerol stock $(20 \%)$ at $-80^{\circ} \mathrm{C}$ and activated twice in appropriate broth before use. Enterococcus feacium DB1 was cultured in MRS medium (Difco, USA). L. monocytogenes was cultured in brain heart infusion (Difco, USA) at $37^{\circ} \mathrm{C}$.

\section{Bacteriocin DB1 assay}

Antimicrobial activity of $E$. feacium DB1 was investigated by agar well diffusion assay. In an agar well diffusion assay, E. feacium DB1 was grown in MRS broth for $16 \mathrm{~h}$ at $37^{\circ} \mathrm{C}$, and the supernatant was obtained by centrifugation (Sorvall RC-5C Plus, Dupont Co., USA) at 6,000 g for 10 $\min$ at $4^{\circ} \mathrm{C}$. The $\mathrm{pH}$ of supernatant was adjusted to 6.5 by adding $5 \mathrm{~N} \mathrm{NaOH}$, and filtered through $0.22 \mu \mathrm{m}$-pore-size cellulose acetate filter (Advantec Dismic-13CP, Toyo-Rochi, Japan). Each aliquot of $100 \mu \mathrm{L}$ of cell-free supernatant was placed into wells (diameter of $9 \mathrm{~mm}$ ) of the agar plate pre-inoculated with indicator strains $\left(\leq 10^{7} \mathrm{CFU} / \mathrm{g}\right)$, and the plates were kept at $4^{\circ} \mathrm{C}$ for $4 \mathrm{~h}$ to allow for diffusion before incubation. After $24 \mathrm{~h}$ of incubation, the plates were observed for the presence of inhibition zone. The bacteriocin titer was determined by the serial 2-fold dilution method against $L$. monocytogenes ATCC 19111. The bacteriocin titer was defined as arbitrary units $(\mathrm{AU} / \mathrm{mL})$. One $\mathrm{AU}$ was defined as the reciprocal of the highest dilution at which the growth inhibition was detectable.

\section{Selection of the best carbon source for bacteriocin production}

The MRS broth contains peptone, beef extract, yeast extract, glucose, polysorbate 80 , ammonium citrate, sodium acetate, magnesium sulfate, manganese sulfate, and dipotassium phosphate. For selection of the best carbon source, some carbon sources were tested individually: glucose, lactose, mannose, fructose, maltose, sucrose, and sorbitol. Each carbon source was added at $2 \%(\mathrm{w} / \mathrm{v})$ of the basal MRS medium, replacing the $2 \%$ glucose. After inoculation of $E$. feacium DB1 (1\% of inoculum), incubation was performed at $37^{\circ} \mathrm{C}$. During the $27 \mathrm{~h}$ of growth cycle, samples were taken at every $2 \mathrm{~h}$ intervals and measured $\mathrm{pH}$, and optical density (OD) under $600 \mathrm{~nm}$ wavelength using spectrophotometer (Smart Plus SP-1900PC, Woongki Science, South Korea). The antimicrobial activity was also measured at every $2 \mathrm{~h}$ by using agar well diffusion test. Ten $\mathrm{mL}$ of cultures were aseptically taken and centrifuged $(10,000 \mathrm{~g}, 15$ $\min$ at $4^{\circ} \mathrm{C}$ ). The $\mathrm{pH}$ of supernatant was adjusted to 6.5 and filtered through $0.22 \mu \mathrm{m}$-pore size cellulose acetate filter. Cell-free supernatant was assayed using serial 2-fold dilution. Sterile MRS broth was used as diluents. Each diluted cell free supernatant $(100 \mu \mathrm{L})$ was loaded on well $(9 \mathrm{~mm})$ of BHI agar lawn containing L. monocytogenes ATCC 19111. The antimicrobial activity of bacteriocin DB1 was expressed as AU/mL. All experiments were performed in duplicate. 


\section{Experimental design of RSM}

After selection of the best carbon source, the next step was to determine the optical levels of three variables (temperature, initial $\mathrm{pH}$ and sucrose concentration) on bacteriocin production. For this purpose, the response surface approach by using a set of experimental design (central composite design, $\mathrm{CCD}$ ) was performed. For the three factors, this design was made up of a full $2^{3}$ factorial design with its eight points augmented with six replications of the center points (all factors at level 0) and the six star points, that is, points having for one factor an axial distance to the center of $\pm \alpha$, whereas the other two factors are at level 0 . In most cases the full $2^{\mathrm{n}}$ factorial design is used in the cube portion in a CCD and thus the $\alpha$ value is calculated with the following formula (Ruguo, 1999):

$$
\alpha=\frac{\left[\left[\sqrt{2^{n}+2 \times \mathrm{n}+\mathrm{r}}-2^{n / 2}\right]^{2} \times 2^{n}\right]^{0.25}}{\sqrt{2}}
$$

In this study, the axial distance $\alpha$ was chosen to be 1.68 to make this design orthogonal. The central composite design was proceeded to obtain a quadratic model, consisting of trials plus a star configuration to estimate quadratic effects and central points to estimate the pure process variability and reassess gross curvature, with active substances production as response. The CCD used was generated by "Minitab" software (version 15). According to this design, 20 experiments were conducted containing six replications at the center point for estimating the purely experimental uncertainty variance. In this study, three key variables with three concentration levels were adopted. To test the influence of sucrose concentration, sucrose was added as 9,20 , and $31 \mathrm{~g} / \mathrm{L}$. To test the effect of the initial $\mathrm{pH}$ on bacteriocin production, MRS media were adjusted to different $\mathrm{pH}$ values (pH 5.5, 6.5, 7.5) with $5 \mathrm{~N} \mathrm{NaOH}$ or $5 \mathrm{~N} \mathrm{HCl}$. To test the effect of the incubation temperature on bacteriocin production, modified MRS media were adjusted to different temperature $\left(30,37\right.$, and $\left.44^{\circ} \mathrm{C}\right)$.

And each variable was designated as $-1,0$, and +1 , respectively, given in Table 2 . The central values $(0$ level) chosen for experimental design were: temperature, $37^{\circ} \mathrm{C}$; initial $\mathrm{pH}, 6.5$ and sucrose concentration, $20 \mathrm{~g} / \mathrm{L}$. In developing the regression equation, the test factors were coded according to the following equation:

$$
x i=\frac{X i-X o}{\Delta X i}
$$

Where $x i$ is the coded value of the $i$ th independent variable, $X i$ the natural value of the $i$ th independent variable, $X_{0}$ the natural value of the $i$ th independent variable at the
Table 1. Growth and bacteriocin production of $E$. faecium DB1 with different carbon sources

\begin{tabular}{lcc}
\hline \hline Modified MRS media & $\begin{array}{r}\text { Growth } \\
\left(\mathrm{OD}_{600}\right)\end{array}$ & $\begin{array}{r}\text { Bacteriocin activity } \\
(\mathrm{AU} / \mathrm{mL})^{1)}\end{array}$ \\
\hline Not added & 0.850 & 160 \\
Glucose & 3.065 & 1280 \\
Lactose & 2.870 & 1280 \\
Mannose & 2.685 & 1280 \\
Fructose & 1.975 & 640 \\
Maltose & 3.175 & 1280 \\
Sucrose & 3.245 & 2560 \\
Sorbitol & 0.935 & 320
\end{tabular}

${ }^{1)} \mathrm{AU} / \mathrm{mL}$ represents the reciprocal of the highest inhibitory dilution in the two-fold dilution assay of bacteriocin.

Table 2. Coded and real values of variables in factional factorial design

\begin{tabular}{lccc}
\hline \multirow{2}{*}{\multicolumn{1}{c}{ Variables }} & \multicolumn{3}{c}{ Level of variables } \\
\cline { 2 - 4 } & -1 & 0 & 1 \\
\hline $\mathrm{X}_{1}$ : Sucrose $(\mathrm{g} / \mathrm{L})$ & 9 & 20 & 31 \\
$\mathrm{X}_{2}$ : Temperature $\left({ }^{\circ} \mathrm{C}\right)$ & 30 & 37 & 44 \\
$\mathrm{X}_{3}$ : Initial $\mathrm{pH}$ & 5.5 & 6.5 & 7.5 \\
\hline
\end{tabular}

center point, and $\Delta X i$ the step change value ( $\Delta X i$ is 7 for temperature, 1 for initial $\mathrm{pH}$, and 11 for sucrose concentration). The levels of these three variables were selected to approach the region where high bacteriocin activity was expected. If the difference was significant between the mean of the center points and that of the factorial points $(p<0.05)$, the optimum would be near or within the experimental design space. Otherwise the optimum would be outside the experimental design space and the method of steepest ascent should be applied (Xiaojie et al., 2003). The central composition design of four variables in coded along with titer as responses is presented in Table 3 .

\section{Results and Discussion}

\section{Selection of the best carbon source for bacteriocin production}

The effect of the carbon source on cell growth and bacteriocin production was determined using MRS medium supplemented with $2 \%$ of different carbon sources in place of glucose. As shown in Fig. 1, the highest growth was observed in medium containing sucrose; maltose, glucose and lactose were also suitable carbon sources for growth. Among the media tested, the E. faecium DB1 produced maximum bacteriocin in sucrose $(2,560 \mathrm{AU} / \mathrm{mL})$ (Fig. 2). 
Table 3. Experimental design and results of central composite design for optimization of bacteriocin production

\begin{tabular}{|c|c|c|c|c|}
\hline \multirow[b]{2}{*}{ Run } & \multicolumn{3}{|c|}{ Variables } & \multirow{2}{*}{$\begin{array}{c}\text { Bacteriocin } \\
\text { production } \\
(\mathrm{AU} / \mathrm{mL})\end{array}$} \\
\hline & $\begin{array}{c}\mathrm{X}_{1} \\
\text { Sucrose }(\mathrm{g} / \mathrm{L})\end{array}$ & $\begin{array}{c}\mathrm{X}_{2} \\
\text { Temperature }\left({ }^{\circ} \mathrm{C}\right)\end{array}$ & $\begin{array}{c}\quad \mathrm{X}_{3} \\
\text { Initial } \mathrm{pH}\end{array}$ & \\
\hline 1 & -1 & -1 & 1 & 1280 \\
\hline $2^{*}$ & 1.682 & 0 & 0 & 2560 \\
\hline 3 & 1 & 1 & 1 & 320 \\
\hline $4 c$ & 0 & 0 & 0 & 1280 \\
\hline $5 \mathrm{c}$ & 0 & 0 & 0 & 1280 \\
\hline 6 & -1 & -1 & -1 & 1280 \\
\hline $7^{*}$ & 0 & -1.682 & 0 & 1280 \\
\hline $8 \mathrm{c}$ & 0 & 0 & 0 & 2560 \\
\hline $9 \mathrm{c}$ & 0 & 0 & 0 & 2560 \\
\hline 10 & 1 & -1 & 1 & 1280 \\
\hline $11^{*}$ & 0 & 0 & 1.682 & 640 \\
\hline $12^{*}$ & -1.682 & 0 & 0 & 1280 \\
\hline 13 & -1 & 1 & 1 & 640 \\
\hline 14 & -1 & 1 & -1 & 640 \\
\hline $15 c$ & 0 & 0 & 0 & 2560 \\
\hline $16^{*}$ & 0 & 0 & -1.682 & 80 \\
\hline 17 & 1 & 1 & -1 & 640 \\
\hline 18 & 1 & -1 & -1 & 1280 \\
\hline $19 \mathrm{c}$ & 0 & 0 & 0 & 2560 \\
\hline $20^{*}$ & 0 & 1.682 & 0 & 80 \\
\hline
\end{tabular}

c, center point; ${ }^{*}$, axial point

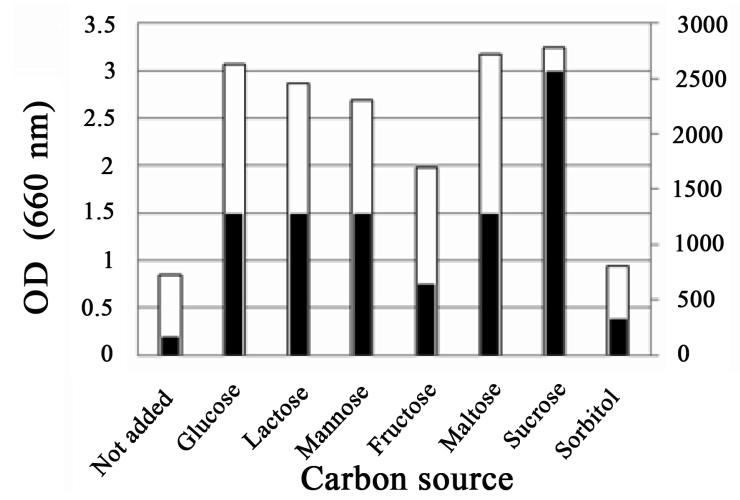

Fig. 1. Effect of carbon sources on cell growth $(\square)$ and bacteriocin DB1 production ( $\square)$ in E. faecium DB1.

Several authors reported that higher bacteriocin activities were observed with increased carbon concentrations, thus our results showing lower bacteriocin recovery with reduced carbon source are not surprising. Although E. faecium DB1 grew without carbon source, there was no bacteriocin production (Fig. 1). This growth may be derived from the utilization of residual sugar or another nutrient, such as yeast extract or peptone, present in MRS medium in sufficient

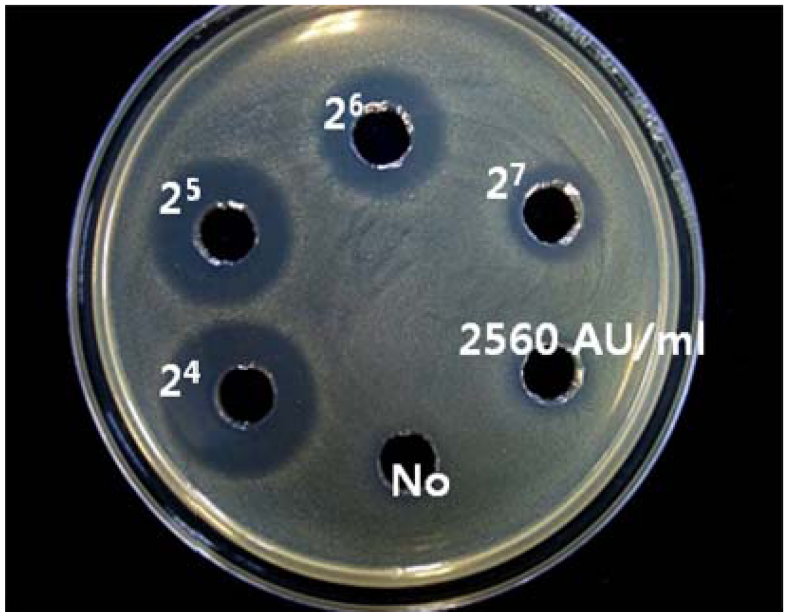

Fig. 2. Antimicrobial activity of bacteriocin DB1 in modified MRS medium containing sucrose against $L$. monocyrogenes by agar well diffusion assay.

quantities to allow E. faecium growth but insufficient for normal synthesis of bacteriocin. Bacteriocin activities do not always correlate with cell concentration or growth rate of the producer (Bogovic-Matijasic and Rogelj, 1998). Higher levels of bacteriocin production are often given at conditions that differ from those required for optimal growth (Aesen et al., 2000; Krier et al., 1998; Parente and Ricciardi, 1994).

The soil environment contains a variety of carbohydrates derived from plant, animal and microbial material that are available to heterotrophic bacteria as carbon source. The bacterial species using these carbohydrates produce a range of enzymes to facilitate this process, some of which are extracellular and are exported into the environment to break down the carbohydrates into smaller entities that can be taken up by the bacterium and metabolized.

Glucose is considered the main carbon source by all microorganisms due to its size, rapid uptake, utilization and cellular energy conversion. However, some bacteria have a complete enzymatic machine that allows them to use complex carbohydrates; for example, E. faecium shows a variable sucrose fermentation pattern (Barnes, 1964).

Sucrose is composed of a glucose unit linked to a fructose unit via a glycosidic linkage, and it is the most abundant disaccharide in the environment because of its origin in higher plant tissues. Three main classes of enzymes have been implicated in the formation and cleavage of glycoside linkages, including the catabolic enzymes, the sucrose hydrolases and phosphorylases (Kitaoka and Hayashi, 2002), and the biosynthetic glycosyl nucleotide glycosyltransferases, which are responsible for the synthesis of carbohydrate polymers produced by bacteria (Steinmetz, 1993). 

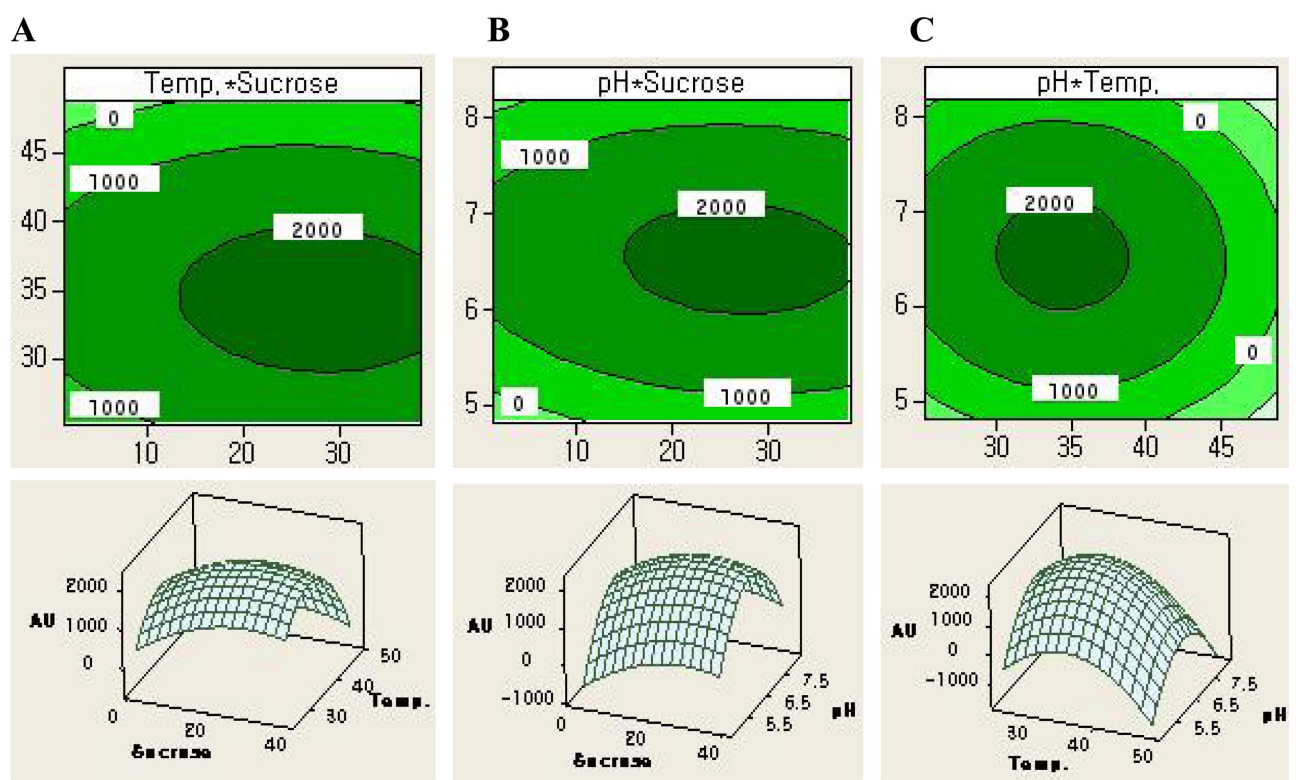

Fig. 3. 2D contour plot and 3D response surface curve. A, temperature and sucrose concentration; B, initial $\mathrm{pH}$ and sucrose concentration; $\mathrm{C}$, initial $\mathrm{pH}$ and temperature

A number of different enzymes, belonging to either the hydrolytic or the phosphorolytic class, catalyze the catabolism of intracellular sucrose. These enzymes catalyze the hydrolysis of terminal fructose moieties from fructose-containing disaccharides, trisaccharides and polymers, with varying specificity. The most well-characterised enzymes within this group are sucrose-6-phosphate $(\mathrm{P})$ hydrolases which cleave sucrose-6-P to yield glucose-6-P and fructose, and which are usually associated with the phosphoenolpyruvate-dependent phosphotransferase system (PTS). The fructose resulting from the catabolism of either sucrose or sucrose-6-P is generally phosphorylated by ATP-dependent fructokinases to give fructose-6-P, an intermediate in the glycolytic pathway. The glucose-6-P generated by the sucrose-6-P hydrolases directly in corporated into the glycolytic pathway.

Type and concentration of carbon sources reported are the most influent factors in bacteriocin production (Delgado et al., 2007). Several authors reported that glucose and sucrose were reported to be suitable carbon sources for nisin Z production (Matsusaki et al., 1996), lactose for nisin-like bacteriocin production (Cheigh et al., 2002), glucose for Streptococcin AFF22 production (John and Ingrid, 1991), nisin production is affected by carbon source regulation, nitrogen sources and phosphorus (De Vuyst and Vacdamme, 1992; De Vuyst and Vacdamme, 1993). However our results showed that only sucrose was more suitable carbon source for bacteriocin DB1 production than glucose or lactose. Therefore, more study is needed to reveal the correct mechanism of sucrose as a carbon source.

\section{Response surface methodology}

The results of central composite design experiments for studying the effects of three variables, sucrose concentration, temperature, and initial $\mathrm{pH}$, on bacteriocin production are presented in Table 3. The corresponding response surface is shown in Fig. 3A, 3B, and $3 \mathrm{C}$, where a point for maximal bacteriocin production can be found. Fig. 3A shows 2D contour plot and 3D response surface curve for variation in the yields of bacteriocin. From the response surface plots, it is easy and convenient to understand the interactions between two variables. The optimum values of the tested variables for the production of bacteriocin were $27.66 \mathrm{~g} / \mathrm{L}$ sucrose, temperature $34.37^{\circ} \mathrm{C}$ and initial $\mathrm{pH} 6.54$. In comparison to the production of MRS medium, 2.08-fold increase had been obtained.

The effects of $\mathrm{pH}$ and temperature are very important for bacteriocin production and have been reported for several bacteriocins produced by E. faecium (Parente and Ricciardi, 1994), L. casei (Vignolo et al., 1995) and L. mesenteroides (Krier et al., 1998). Using the RSM methodology, we demonstrate that these parameters are also fundamental for bacteriocin production by E. faecium DB1 as well. Decrease in bacteriocin productivity at high sucrose concentration could be explained by a relatively high lactic acid concentration, which might inhibit cell growth and bacteriocin production.

The traditional "one-factor-at-a-time approach" is an operation frequently used in medium optimization to obtain 
high yields of the desired metabolic products in a microbial system. But that method disregards the complex interactions among various physicochemical parameters (AbdelFattah et al., 2005). Statistically based experimental designs such as factorial design and response surface analysis particularly fulfills this requirement. RSM can be used to study the effects of several factors influencing the responses by varying them simultaneously and carrying out a limited number of experiments (Elibol, 2004; Piyushkumar et al., 2007).

RSM has been a popular and effective method to solve multivariate problems and optimize responses in many types of experimentation (Dale et al., 2007; Park et al., 2007). The method of RSM for improvement of fermentation was described in detail by Strobel and Sullivan (Strobel and Sullivan, 1999). As large amounts of bacteriocin are necessary to test their preservative efficiency in natural environments, establishment of the factors and levels influencing maximal production would lead to a more effective recovery of these antimicrobial compounds from a defined laboratory culture medium (Aymerich et al., 2000; Daeschel and Hoover, 1993).

\section{Acknowledgement}

This research was supported by the Agriculture Research Center program of the Ministry for Food, Agriculture, Forestry and Fisheries, Korea.

\section{References}

1. Abdel-Fattah, Y. R., Saeed, H. M., Gohar, Y. M., and El-Baz, M. A. (2005) Improved production of Pseudomonas aeruginosa uricase by optimization of process parameters through statistical experimental designs. Process Biochem. 40, 17071714.

2. Aesen, I. M., Møretrø, T., Katla, T., Axelsson, L., and Storro, I. (2000) Influence of complex nutrients, temperature and $\mathrm{pH}$ on bacteriocins production by Lactobacillus sakei CCUG 42687. Appl. Microbiol. Biotechnol. 53, 159-166.

3. Adinarayana, K., Ellaiah, P., Srinivasulu, B., Devi, R. B., and Adinarayana, G. (2003) Response surface methodological approach to optimize the nutritional parameters for neomycin production by Streptomyces marinensis under solid-state fermentation. Process Biochem. 38, 1565-1572.

4. Aymerich, T., Artigas, M. G., Garriga, M., Monfort, J. M., and Hugas, M. (2000) Effect of sausage ingredients and additives on the production of enterocin A and B by Enterococcus faecium CTC492. Optimization of in vitro production and anti-listerial effect in dry fermented sausages. J. Appl. Microbiol. 88, 686-694.
5. Barnes, E. M. (1964) Distribution and properties of serological types of Streptococcus faecium, Streptococcus durans and related strains. J. Appl. Bacteriol. 27, 461-470.

6. Bogovic-Matijasic, B. and Rogelj, I. (1998) Bacteriocin complex of Lactobacillus acidophilus LF221-production studies in MRS-media at different $\mathrm{pH}$-values and effect against Lactobacillus helveticus ATCC 15009. Process. Biochem. 33, 345-352.

7. Cheigh, C. I., Choi, H. J., Park, H., Kim, S. B., Kook, M. C., Kim, T. S., Hwang, J. K., and Pyun, Y. R. (2002) Influence of growth conditions on the production of a nisin-like bacteriocin by Lactococcus lactis subsp. lactis A164 isolated from kimchi. J. Biotech. 95, 225-235.

8. Cleveland, J., Montville, T. J., Nes, I. F., and Chikindas, M. L. (2001) Bacteriocins: safe, natural antimicrobials for food preservation. Int. J. Food Microbiol. 71, 1-20.

9. Cotter, P. D., Hill, C., and Ross, R. P. (2005) Bacteriocins: developing innate immunity for food. Nat. Rev. 3, 777-788.

10. Daeschel, M. A., Hoover, D. G., and L. R. Steenson. (1993) Applications and interactions of bacteriocins from lactic acid bacteria in foods and beverages. Bacteriocins of lactic acid bacteria. Academic Press, Inc., NY. pp. 63-91.

11. Dale, B. M., Walter, J. G., Wayne, L. T., and Michael, J. M. (2007) Global and local optimization using radial basis function response surface models. Appl. Math. Model 31, 20952110.

12. De Vuyst, L. and Vandamme, E. J. (1992) Influence of the carbon source on nisin production in Lactococcus lactis subsp. lactis batch fermentations. J. Gen. Microbiol. 138, 571-578.

13. De Vuyst, L. and Vandamme, E. J. (1993) Influence of the phosphorus and nitrogen source on nisin production in Lactococcus lactis subsp. lactis batch fermentations using a complex medium. Appl. Microbiol. Biotechnol. 40, 17-22.

14. De Vuyst, L. (1995) Nutritional factors affecting nisin production by Lactococcus lactis lactis NIZO 22186 in a synthetic medium. J. Appl. Bacteriol. 78, 28-33.

15. Delgado, A., Noé-Arroyo López, F., Brito, D., Peres, C., Fevereiro, P., and Garrido-Fernández, A. (2007) Optimum bacteriocin production by Lactobacillus plantarum $17.2 \mathrm{~b}$ requires absence of $\mathrm{NaCl}$ and apparently follows a mixed metabolite kinetics. J. Biotechnol. 130, 193-201.

16. Elibol, M. (2004) Optimization of medium composition for actinorhodin production by Streptomyces coelicolor A3(2) with response surface methodology. Process Biochem. 39, 10571062.

17. Floriano, B., Ruiz-Barba, J. L., and Jimenez-Diaz, R. (1998) Purification and genetic characterization of enterocin I from Enterococcus faecium 6T1a, a novel antilisterial plasmid encoded bacteriocin which does not belong to the pediocin family of bacteriocins. Appl. Environ. Microb. 64, 4883-4890.

18. Food and Drug Administration (1998) Nisin preparation: affirmation of GRAS status as a direct human food ingredient. Fed. Regist. 53, 11247-11251.

19. Foulquie' Moreno, M. R., Sarantinopoulos, P., Tsakalidou, E., and De Vuyst, L. (2006) The role and application of enterococci in food and health. Int. J. Food Microbiol. 106, 1-24.

20. Franz, C. M., Holzapfel, W. H., and Stiles, M. E. (1999) 
Enterococci at the crossroads of food safety? Int. J. Food Microbiol. 47, 1-24.

21. Gänzle, M., Weber, S., and Hammes, W. (1999) Effect of ecological factors on the inhibitory spectrum and activity of bacteriocins. Int. J. Food Microbiol. 46, 207-217.

22. Gelsomino, R., Vancanneyt, M., Condon, S., Swings, J., and Cogan, T. M. (2001) Enterococcal diversity in the cheese making environment of an Irish Cheddar-type cheese making factory. Int. J. Food Microbiol. 71, 177-188.

23. Giraffa, G., Carminati, D., and Torri Tarelli, G. (1995) Inhibition of Listeria innocua in milk by bacteriocin-producing Enterococcus faecium 7C5. J. Food Prot. 58, 621-623.

24. Giraffa, G. (2003) Functionality of enterococci in dairy products. Int. J. Food Microbiol. 88, 215-222.

25. Jack, R. W., Tagg, J. R., and Ray, B. (1995) Bacteriocins of gram-positive bacteria. Microbiol. Rev. 59, 171-200.

26. Park, J. S., Woo, J. S., and Hwang, S. J. (2007) Development and optimization of a novel oral controlled delivery system for tamsulosin hydrochloride using response surface methodology. Int. J. Pharm. 341, 97-104.

27. John, W. M. M. and Ingrid, J. B. (1991) Identification and characterization of the lantibiotic nisin variant. Eur. J. Biochem. 201, 581-584.

28. Kim, W. J. (1993) Bacteriocins of lactic acid bacteria: their potentials as food biopreservative. Food Rev. Int. 9, 299-313.

29. Kitaoka, M. and Hayashi, K. (2002) Carbohydrate-processing phosphorolytic enzymes. Trends Glycosci. Glycotechnol. 14, 35-50.

30. Klaenhammer, T. R. (1993) Genetics of bacteriocins produced by lactic acid bacteria. FEMS Microbiol. Rev. 12, 39-85.

31. Krier, F., Revol-Junelles, A. M., and Germain. P. (1998) Influence of temperature and $\mathrm{pH}$ on production of two bacteriocins by Leuconostoc mesenteroides subsp. mesenteroides FR52 during batch fermentation. Appl. Microbiol. Biotechnol. 50, 359-363.

32. Leal-Sánchez, M. V., Jiménez-Díaz, R., Maldonado-Barragán, A., Garrido-Fernández, A., and Ruiz-Barba, J. L. (2002) Optimization of bacteriocin production by batch fermentation of Lactobacillus plantarum LPCO10. Appl. Environ. Microbiol. 68, 4465-4471.

33. Lee H. J. and Kim, W. J. (2010) Isolation and characterization of anti-listerial and amylase sensitive enterocin producing Enterococcus faecium DB1 from gajami-sikhae, A fermented flat fish in Korea. Food Sci. Biotechnol. 19, 373-381.

34. Li, C., Bai, J., Cai, Z., and Ouyang, F. (2001) Optimization of a cultural medium for bacteriocin production by Lactococcus lactis response surface methodology. J. Biotechnol. 93, 27-34.

35. Matsusaki, H., Endo, N., Sonomoto, K., and Ishizaki, A. (1996) Lantibiotic nisin Z fermentative production by Lactococcus lactis 10-1: relationship between production of the lantibiotic and lactate and cell growth. Appl. Microbiol. Biotechnol. 45, 36-40.

36. Oh, S., Rheem, S., Sim, J., Kim, S., and Baek, Y. (1995) Optimizing conditions for the growth of Lactobacillus casei YIT 9018 in tryptone-glucose medium by using response surface methodology. Appl. Environ. Microb. 61, 3809-3814.

37. O'Sullivan, L., Ross, R. P., and Hill, C. (2002) Potential of bacteriocin producing lactic acid bacteria for improvements in food safety and quality. Biochimie. 84, 593-604.

38. Parente, E. and Ricciardi, A. (1994) Influence of $\mathrm{pH}$ on the production of enterocin 1146 during batch fermentation. Lett. Appl. Microbiol. 19, 12-15.

39. Piyushkumar, M., Kiran, D., and Lele, S. S. (2007) Application of response surface methodology to cell immobilization for the production of palatinose. Bioresource Technol. 98, 2892-2896.

40. Reunanen, J. and Saris, P. E .J. (2009) Survival of nisin activity in intestinal environment. Biotechnol. Lett. 31, 1229-1232.

41. Ross, R.P., Galvin, M., McAuliffe, O., Morgan, S. M., Ryan, M. P., Twomey, D. P., Meaney, and W. J., Hill, C. (1999) Developing applications for lactococcal bacteriocins. Antonie van Leeuwenhoek 76, 337-346.

42. Ruguo Ho (1999) Food product design. CRC Press, Boca Raton London New York Washington, DC. pp. 56-59.

43. Sabia, C., Manicardi, G., Messi, P., de Niederhausern, S., and Bondi, M. (2002) Enterocin 416K1, an antilisterial bacteriocin produced by Enterococcus casseliflavus IM 416K1 isolated from Italian sausages. Int. J. Food Microbiol. 75, 163-170.

44. Senesi, S., Celandroni, F., Tavanti, A., and Ghelardi, E. (2001) Molecular characterization and identification of Bacillus clausii strains marketed for use in oral bacteriotherapy. Appl. Environ. Microb. 67, 834-839.

45. Settanni, L. and Corsetti, A. (2008) Application of bacteriocins in vegetable food biopreservation. Int. J. Food Microbiol. 121, 123-138.

46. Steinmetz, M. (1993) Carbohydrate catabolism: pathways, enzymes, genetic regulation, and evolution. In: Bacillus subtilis and other Gram-positive bacteria: biochemistry, physiology and molecular genetics. Sonenshein, A. L. (ed) ASM, Washington, DC, pp. 157-170.

47. Strobel, R. J. and Sullivan, G. R. (1999) Manual of industrial microbiology and biotechnology, 2nd ed, ASM Press, Washington, DC.

48. Vignolo, G. M., Kairuz, M. N., Ruiz-Holgado, A. A. P., and Oliver, G. (1995) Influence of growth conditions on the production of lactocin 705, a bacteriocin produced by Lactobacillus casei CRL 705. J. Appl. Bacteriol. 78, 5-10.

49. Xiaojie, L., Guoqing, H., Qihe, C. (2003) Culture medium optimization for producing cellulose by Trichoderma koningii ZJ5. J. Zhejiang Univ. (-Sc. A). 5, 623-628.

(Received 2009.8.5/Revised 2010.12.28/Accepted 2011.2.14) 